\title{
Quality assurance of yoghurt during processing
}

\author{
Saadia H. H. El- Shinawy*, A. M. El Kholy, M. M. A. Zeinhom \\ Department of Food Hygiene, Faculty of Veterinary Medicine, Beni-Suef University
}

\begin{abstract}
The present study was carried out to determine the critical points during processing of yoghurt, through examination of Acidity \% and Storch's test to detect the efficiency of heat treated milk samples and Microbiological examination of samples collected weekly over a period of 7 months for TCC, Thermoduric, Total coliform, Faecal coliform, E. coli, Enterococci, S. aureus, Yersinia enterocolitica and Total yeast and mould counts. A total of 100 samples of raw milk, heat treated milk, inoculated milk and yoghurt (25 of each) in addition to 75 samples from worker's hands, plastic packages and mixing vat (25 of each) were collected under strict hygienic conditions, also twenty five samples of yoghurt at the end of the expire date were collected and examined microbiologically. The obtained results concluded that the major sources of yoghurt contamination were raw milk, improperly cleaned and sanitized worker's hands as well as the added starter culture. Finally, the public health and economic importance of the isolated organisms were mentioned.
\end{abstract}

Yoghurt is the most popular fermented milk produced in Egypt and worldwide. The great popularity of yoghurt is due to its refreshing and thirst-quenching in hot weather. The value of yoghurt in human nutrition is based not only on the nutritive value of milk from which it is made and increased digestibility due to changes of milk constituents during the fermentation period, but also on the beneficial effect on intestinal microflora and on healing effects (Heyman, 2000; Zedan et al., 2001).

The quality term of a dairy product is defined as its measurement against a standard regarded as excellent at a particular price which is satisfactory for both the producer and consumer. Quality can be judged by the subjective tests include physical properties, chemical composition, and microbial flora [both quantitative and qualitative (Hayes, 1992).

Escherichia coli in foods is an indicator of direct or indirect fecal contamination, they are known as food quality parameters (Jay, 1996) .Also, the high counts of E. coli and total coliforms in foods usually indicate careless production and handling of processed products as well as insufficient sanitization of equipment.

Also some members of coliforms are responsible for the development of objectionable taints in milk and its products rendering them of inferior quality or even unmarketable (Banwart, 1998). Moreover certain serovars of E. coli are associated with infantile diarrhoea, gastroenteritis and food poisoning among

\footnotetext{
* Corresponding author. Tel.: +20 082 2322066;

Fax: +20 0822327982

E-mail address: s.h.elshinawy@bsu.edu.eg

(Saadia H. H. El-Shinawy)
}

consumers (Forsythe, 2000).

Enterococci are of interest due to their characteristics of being the most thermo-resistant among the non-sporulated microorganisms and provide a good general index of faecal contamination, good manufacturing practice (GMP) as well as food quality in dairy farms and factories of fermented milks. Moreover, they are responsible for food poisoning (Roushdy et al., 1998).

S.aureus produces a number of extra cellular compounds of most important is Staphylococcal enterotoxins, which is responsible for Staphylococcal food poisoning. S.aureus is almost transmitted to food from the mammary glands of dairy animals and human sources e.g. food handlers (Adrian, 1994), or by cross contamination from another sources such as utensils previously contaminated by humans.

Yersinia organisms are psychrotrophic gram negative milk borne enteric pathogens. These organisms are widespread in the environment and are indigenous to the gastrointestinal tracts of worm-blooded animals including dairy cattle (Marshall, 1992). Several outbreaks of food poisoning caused by Yersinia enterocolitica were reported due to consumption of raw milk and its products (Eley, 1996).

Presence of yeasts and moulds in dairy products is undesirable even when found in a few numbers as they rapidly grow in the product at a wide range of temperature, $\mathrm{pH}$ and humidity resulting in objectionable changes that render the product of inferior quality or even unmarketable (Mossel, 1982). Moreover, they constitute public 
health hazard among consumers (Varnam and Sutherland, 1994).

Therefore, the present study was carried out to detect the quality and the sources of contaminations of yoghurt during manufacturing through the following: Sanitary examinations, Microbiological examination and isolation and identification of some pathogens.

\section{Materials and methods}

Collection of samples. A total of 100 samples of raw milk, heat treated milk, inoculated milk and yoghurt ( 25 of each) in addition to 75 samples from worker's hands, plastic packages and mixing vat (25 of each) were collected weekly for seven months under strict hygienic conditions in a sterile screw capped bottles and/or in their containers (Dewit and Kamplmacher, 1981; APHA, 1992a). The samples for microbiological examination were dispatched directly to the laboratory with a minimum of delay in an ice- box. Also twenty five samples of yoghurt at the end of the expire date were collected and examined microbiologically.

Preparation of samples. It was adopted according to (APHA, 1992a).

Sanitary examination. Determination of acidity was performed according to (Ling, 1963) while Storch's test according to (Lampert, 1975).

Micobiological examination. Total colony count was performed according to (TCC) (APHA, 1992a), total coliforms, faecal coliforms and $E$. coli (APHA, 1992a), enterococci count (Mossel et al., 1978). Enumeration, isolation and identification of S.aureus (APHA, 1992b). Isolation and identification of Yersinia enterocolitica (Schiemann and Wauters, 1992). Yeasts and moulds counts (Oxoid, 1998).

\section{Results and Discussion}

It is evident from the recorded results in Table (1) and Fig., (1) that the mean value of acidity $\%$ in raw milk samples was $0.15 \pm 0.004$, Higher values were reported by Farag, (2002).

Normal acidity $\%$ of milk samples are returned to proper cooling after milking. The mean value of acidity in fersh and old yoghurt were $0.71 \pm 0.01$ and $0.91 \pm 0.01$, respectively. Higher values were recorded by (Libouga et al., 2005). The variation in acidity $\%$ may be attributed to the variation in time temperature during preparation and storage as well as to the amount and quality of starter used in the manufacturing.

Storch's test indicated that $100 \%$ of the examined samples were efficiently heated above $80^{\circ} \mathrm{C}$ (Table 2).

The results given in Table (3) revealed that the mean value of TCC in raw milk samples was $5.7 \times 10^{6} \pm 1.2 \times 10^{6} \mathrm{cfu} / \mathrm{ml}$. while in heat treated milk was $5.5 \times 10^{3} \pm 2.4 \times 10^{3} \mathrm{cfu} / \mathrm{ml}$.

Higher results were reported by Chye et al., (2004), while lower results were recorded by Vyletelova, (2005).

For worker's hands, mixing vat and plastic packages the mean values of TCC were $8.3 \times 10^{6}$ $\pm 3.3 \times 10^{6}, 3.7 \times 10^{3} \pm 1.6 \times 10^{3}$ and $1.9 \times 10^{3} \pm$ $5.9 \times 10^{2} \mathrm{cfu} / \mathrm{ml}$, respectively were recorded by Farag, (2002).

The possible reasons for high TCC in raw milk may be attributed to infected udder, unhygienic milking procedure or milking and storage equipment.

The findings reported in Table (3) indicated that the mean values of total coliform counts (MPN/ml or gm) were $1.4 \times 10^{4} \pm 6.0 \times 10^{3},<3 \pm$ $0,2.5 \times 10^{3} \pm 7.7 \times 10^{2}, 6.2 \times 10^{3} \pm 1.0 \times 10^{3}$ and $3.7 \times 10^{3}$ in the examined raw milk, heat treated milk, inoculated milk, fresh yoghurt and old yoghurt samples, respectively.

Higher values for coliform count in raw milk were recorded by Ulusoy, (2006), while lower results were reported by Vyletelova, (2005). Higher results for coliform count in yoghurt were recorded by Libouga et al., (2005), but lower results were reported by Farag, (2002). The mean values of total coliform count for worker's hands, mixing vat and plastic packages were $2.7 \times 10^{2} \pm 8.5 \times 10^{1}, 5.4 \pm 1.8$ and $4.7 \pm$ 1.4 coliforms $/ \mathrm{ml}$, respectively. Higher results for coliform count in worker's hands, mixing vat and plastic packages were recorded Farag, (2002). The heat treatment process reduced the microorganisms to acceptable numbers; however the results showed that the number of total coliforms increased in the yoghurt samples indicating post heat treatment contamination. The probable reasons for this finding were the contamination of worker's hands and the inoculum (starter) with coliforms.

The results presented in Table (3) indicated that the average count of faecal coliforms $\left(\mathrm{MPN} / \mathrm{ml}\right.$ or gm) were $1.2 \times 10^{4} \pm 4.7 \times 10^{3},<3 \pm$ $0,2.4 \times 10^{3} \pm 7.7 \times 10^{2}, 5.9 \times 10^{3} \pm 1.0 \times 10^{3}$ and $2.3 \times 10^{3}$ in the examined raw milk, heat treated milk, inoculated milk, fresh and old yoghurt samples, respectively. Lower results in raw milk were recorded by (Abd El-Hameid, 2002), while higher results were reported by (Ali, 2004). The mean values of faecal coliforms counts (MPN/ml) for worker's hands, mixing vat 
Table (1): Statistical analytical results of acidity $\%$ in examined samples.

\begin{tabular}{lcccc}
\hline Sample & Min. & Max. & Mean & \pm SEM \\
\hline Raw milk & 0.12 & 0.18 & 0.15 & 0.004 \\
$\begin{array}{l}\text { Fresh } \\
\text { yoghurt }\end{array}$ & 0.60 & 0.83 & 0.71 & 0.01 \\
Old yoghurt & 0.81 & 1.10 & 0.91 & 0.01 \\
\hline
\end{tabular}

Table (2): Results of Storch's test in examined heat treated milk samples.
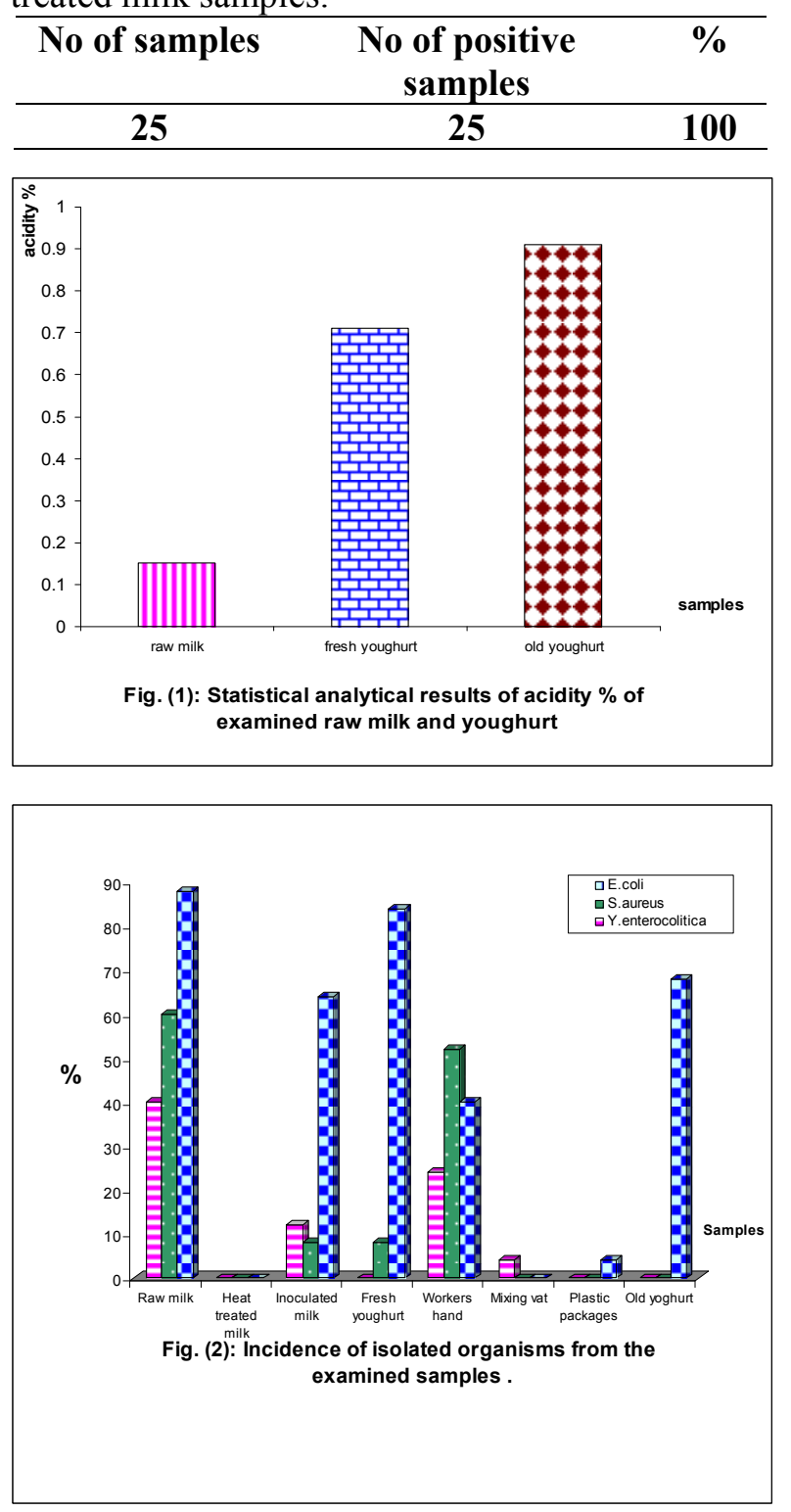

and plastic packages were $2.2 \times 10^{2} \pm 8.1 \times 10^{1}$, $5.4 \pm 1.8$ and $3.2 \pm 0.24$, respectively. Coliforms as an indicator of post processing contamination in yoghurt manufacture had been long established and recommended by public health authorities world wide.

Inspection of results recorded in Table (3) revealed that the mean counts of enterococci were $1.8 \times 10^{3} \pm 4.4 \times 10^{2},<10^{2} \pm 0,1.3 \times 10^{2} \pm$ $4.9 \times 10^{1}, 7.4 \times 10^{2} \pm 3.1 \times 10^{2}$ and $3.2 \times 10^{2}$ $\mathrm{cfu} / \mathrm{ml}$ or gm in examined raw milk, heated milk, inoculated milk, fresh and old yoghurt samples, respectively.

Higher results were reported by (Vyletelova, 2005), while lower results were recorded by (Abd El-Hameid, 2002) in row milk.

In yoghurt samples higher results were recorded by (Libouga et al., 2005), while lower results were recorded by (Rodriquez et al., 1990).

The mean value of enterococci was $5.5 \mathrm{x}$ $10^{2} \pm 3.1 \times 10^{1} \mathrm{cfu} / \mathrm{ml}$., in the examined worker's hands samples, but failed to be detected in the examined mixing vat and plastic packages samples. Absences of enterococci in heat treated milk samples indicate efficiency of heat treatment process, but the presence of Enterococci in raw milk and yoghurt even in few numbers is considered as indication of improper sanitation and / or faecal contamination.

From the results presented in Table (3) it is evident that the mean count of S. aureus in the examined raw milk, heat treated milk, inoculated milk, fresh and old yoghurt samples were $6.7 \mathrm{x}$ $10^{2} \pm 3.5 \times 10^{2},<10^{2} \pm 0,1.3 \times 10^{2} \pm 1.2 \times 10^{2}$, $5.3 \times 10^{1} \pm 5.1 \times 10^{1}$ and $<10^{2} \mathrm{cfu} / \mathrm{ml}$ or gm, respectively. Higher results in raw milk were reported by (Chye et al., 2004), while lower results were reported by (Vyletelova, 2005). Nearly similar results in heat treated milk were reported by (Gomes and Gallo, 1995), but higher results were reported by (Vyletelova and Hanus, 2005).

In yoghurt higher results were recorded by (Ali et al., 2004), while lower results were reported by (Libouga et al., 2005). The mean value of $S$. aureus in worker's hands, mixing vat and plastic packages were $1.8 \times 10^{2} \pm 1.3 \times 10^{2}$, $<10^{2} \pm 0$ and $<10^{2} \pm 0 \mathrm{cfu} / \mathrm{ml}$. According to the limits proposed by (Robinson, 1990); Egyptian Standards, (2001) for S. aureus count in raw milk $\left(10^{2} \mathrm{~S}\right.$. aureus $\left./ \mathrm{ml}\right), 32 \%$ of the examined milk samples were above these limits and this may be attributed to lower sanitation level and presence of boils and abrasions, that may present on teats of dairy animals or worker's hands. Also, the increase incidence of Staphylococcal mastitis among dairy animals and sinusitis among workers are important sources of raw milk contamination.

According to the limits proposed by Egyptian Standards, (1990) that yoghurt must be free from S. aureus, it is obvious that $4 \%$ of the examined samples fail to comply with it.

The presence of $S$. aureus in fresh yoghurt gives an indication about its contamination either 
from starter culture or from skin, mouth, nose of workers handling the dairy product. The greatest inhibitory effect of yoghurt starter culture of this product on undesirable organisms explains the low number of staphylococcus count in the examined fresh yoghurt samples.

At high contamination levels of $S$. aureus the antibacterial effect of yoghurt is insufficient to avoid the risk of food poisoning (Pazakova et al., 1997). Therefore, the potential for Staphylococcal food intoxication cannot be ascertained without testing the enterotoxigenicity of isolated strains and / or detecting of staphylococcal enterotoxin in food.

The results reported in Table (3) proved that the mean counts of yeasts and molds were $7.9 \mathrm{x}$ $10^{4} \pm 2.4 \times 10^{4}, 1.0 \times 10^{1} \pm 7.3,4.1 \times 10^{4} \pm 2.1 \times$ $10^{4}, 8.0 \times 10^{4} \pm 2.7 \times 10^{4}$ and $<10^{2} / \mathrm{ml}$ or gm., in the examined raw milk, heated milk, inoculated milk , fresh and old yoghurt samples, respectively. Lower results in raw and heat treated milk were recorded by (Abd El-Hameid, 2002), but higher results were reported by (Farag, 2002).

In yoghurt samples lower results were reported by (Ali et al., 2004), but higher results were recorded by (Ucar et al., 2001). The mean values of total yeast and mould in the examined worker's hands, mixing vat and plastic packages were $8.8 \times 10^{2} \pm 3.9 \times 10^{2}, 2.6 \times 10^{1} \pm 1.9 \times 10^{1}$, and $1.0 \times 10^{2} \pm 7.5 \times 10^{1} / \mathrm{ml}$, respectively. Higher results in worker's hands, mixing vat and plastic packages were recorded by (Farag, 2002).

The achieved results allow concluding that most of the examined samples proved to be contaminated with yeasts and moulds, which indicate neglected hygienic measures during production, handling, storage and distribution.

Contamination of heat treated milk with yeast and mould may be due to presence of their resistant spores which survive the temperature of heat treatment, also it may be contaminated from the mixing vat or the environmental condition of the plant.

The presence of yeasts and moulds in fresh yoghurt samples may be attributed to contamination from worker's hands, plastic packages and starter culture, and is being indicative of poor sanitary practices in manufacturing, packaging and / or storage.

It's evident from Table (4) that E. coli could be detected in $22(88 \%)$ out of 25 raw milk samples, while it failed to be isolated from heat treated milk, but could be isolated from 64,84 and $68 \%$ of the examined inoculated milk, fresh and old yoghurt samples, respectively.

Lower results in raw milk were recorded by (Kivaria et al., 2006), while lower results in yoghurt were reported by (Dardashti et al., 2001).

E. coli failed to be isolated from mixing vat, while could be detected in 10(40\%) for worker's hands and $1(4 \%)$ for plastic package samples. Since these dairy products are expected to be exposed to heat treatment and fluctuating preservation conditions, isolation of $E$. coli reflects inadequate manufacturing processing of these products, i.e. too short duration of heat treatment or too low temperature, improper storage conditions and violated personal hygiene.

It is evident from the data given in Table (4) that S. aureus were present in $60,0,8$ and $8 \%$ of the examined raw milk, heat treated milk, inoculated milk and fresh yoghurt samples, respectively.

Nearly similar results in raw milk were recorded by Chye et al., (2004), but higher results were recorded by El- Sayed, (1997). On the other hand lower results were recorded by Kivaria et al., (2006).

Nearly similar results in heat treated milk were reported by Gomes and Gallo, (1995), but higher results were reported by Vyletelova and (Hanus, 2005). In yoghurt higher results were recorded by (Zaria et al., 1997). S. aureus failed to be detected in mixing vat and plastic packages, but could be detected in $52 \%$ of the examined worker's hands samples.

Lower results in worker's hands were recorded by (Farag, 2002) but higher results in mixing vat and plastic packages were recorded by (Farag, 2002).

Data presented in Table (4) indicated that the incidence of Y. enterocolitica in raw milk, heat treated milk, inoculated milk and fresh yoghurt samples were $40,0,12$ and $0 \%$, respectively.

Higher incidence in raw milk were recorded by (Ulusoy, 2006), comparatively lower results were reported by Kasalica and Miocinovic, (2004). Nearly similar results in yoghurt were reported by (Hassan, 1999), but higher results were recorded by (El-Prince and Sabreen, 1998).

$Y$. enterocolitica failed to be detected in plastic packages samples, but it was present in proportion of 24 and 4 in the examined worker's hands and mixing vat samples, respectively. $Y$. enterocolitica failed to be detected in yoghurt samples; this may be attributed to some 


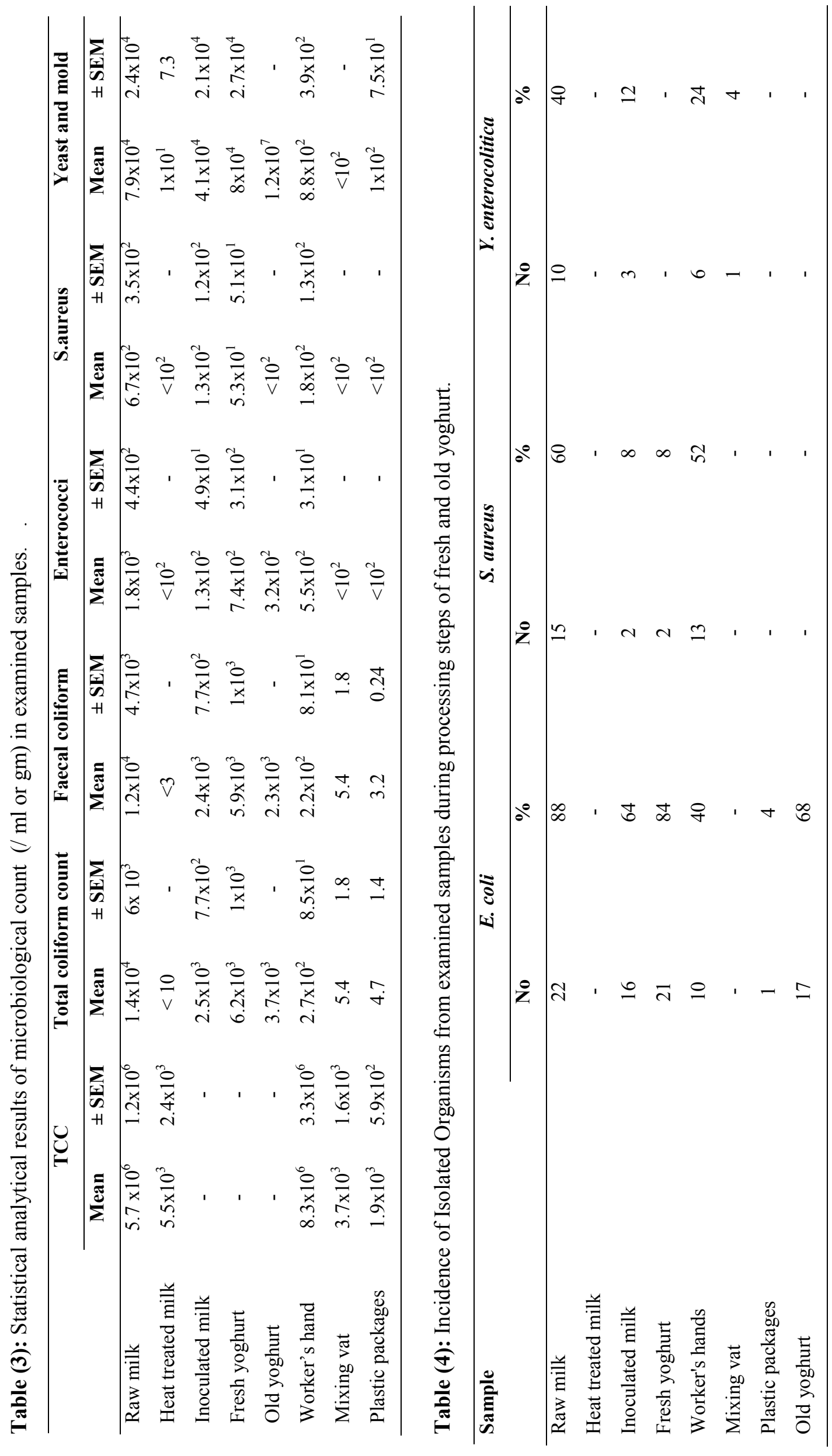


factors as storage temperature (Broklehurst and Lund, 1990). Also the competition of starter culture (Todorvic and Salatic, 1990), due to the inhibitory properties of some metabolites (diacetyl) produced by starter culture bacteria (Motlagh et al., 1991) as well as lactic acid concentrations (EL-Ziney et al., 1997).

\section{Conclusion}

The information derived from analysis of samples during the manufacturing of yoghurt allow to concluded that the major sources of yoghurt contamination were raw milk, improperly cleaned and sanitized worker's hands as well as the added starter culture. Therefore the application of HACCP system must be adopted in both milk production units, milk product processing plants and during transportation and displaying the final product.

\section{Refernces}

Abd El-Hameid, K. G. (2002): Studies on the sanitary conditions of raw milk in Qena Governorate. M.V.Sc. Thesis, Fac. Vet. Med., Assiut Univ., Egypt.

Adrian, R. E. (1994): Microbial food poisoning. Page 3373.

Agerbeak, M.; Gerde, L.V. and Richelsen, B. (1995): Hypocholesterolaemic effect of a new fermented milk product in healthy middle-aged men. Europ. J. Clinical Nutr., 49: 346.

Ali, M. A. H. (2004): Enterobacteriaceae as indicator of sanitary quality for dairy farm milk. M.V.Sc. Thesis, Fac. Vet. Med. Beni-Suef, Cairo Univ. Egypt.

Ali, M.M. ; Wahba, N.M. and Farrag, S. A. (2004): Microbiological evaluation of Assiut market yoghurt through its shelf life time in the refrigerator. Assiut Vet. Med. J. 50(101): 64-77.

APHA, (1992a): Standard methods for the examination of dairy products. $16^{\text {th }}$ Ed., American public health association, Washington.

APHA, (1992b): Compendium of methods for the microbiological examination of foods. $3^{\text {rd }}$ Ed., American public health association, Washington.

Banwart, G. (1998): Basic Food Microbiology. $1^{\text {st }}$ Indian Ed., Chapman \& Hall, Inc., New York.

Brocklehurst, T.F. and Lund, B. M. (1990): The influence of $\mathrm{PH}$, temperature and organic acids on the initiation of growth of Yersinia enterocolitica. J. App. Bacteriol. 69: 390-397.

Chye, F.; Aminah, A. and Mohd-Khan, A. (2004): Bacteriological quality and safety of raw milk in Malaysia. Food- Microbiol., 21(5): 535-541.

Dardashti, A. D.; Afshin, A. and Saeed, B. (2001): Study of coliform, yeast and mould contamination of yoghurt in Ghaemshahr in Iran. Periodicum Biologorum; 103(2): 183186.

Egyptian Standards (2001): Milk and Milk products. Egyptian Organization for Standardization and Quality Control.

Eley, A. R. (1996): Microbial Food Poisoning. 2nd ed., Chapman and Hall, London, UK.

El-Prince, E. and Sabreen, M. S. (1998): Some studies on Yersinia enterocolitica in milk and some dairy products. 8th Scientific Congress, Faculty of Veterinary Medicine, Assuit
University, Egypt (22-32).

El-Sayed, A. A. (1997): Studies on the microbiological quality of raw and pasteurized milk in Sharkia Governorate. M.V.Sc., Thesis, Fac. Vet. Med., Zagazig Univ., Egypt.

El-Ziney, M. G.; Meyer, H. De. and Debervere, J. M. (1997): Growth and survival Kinatics of Yersinia enterocolitica IP 383 0:9 as affected by equimolar concentrations of undissociated short chain organic acids. Int. J. Food Microbiol., 34 (3) 233-247. (1997). Food Sci. \& Tech. Abst. (1997) 29 (6) 83-6C 152.

Farag, H. F. (2002): Hazard analysis of some dairy products and their services establishment in Beheria governorate. A thesis for the degree of ph. D., Fac. Vet. Med., Alx. Univ., Egypt.

Forsythe, S. J. (2000): The Microbiology of safe food. $1^{\text {st }}$ Ed. Blackwell Science Ltd., 25 John Street, London, WC. N: 285.

Gomes, H. A. and Gallo, C. R. (1995): Occurrence of Staphylococcus aureus and enterotoxin production by strains isolated from raw milk, pasteurized milk type $\mathrm{C}$ and Minas Frescal cheese commercially-produced in Piracicaba SP. Ciencia-e-Tecnologia-de-Alimentos. 15(2): 158-161.

Hassan, G. M. (1999): Studies on Yersinia organisms in raw milk and some dairy products marketed in Beni-Suef governorate. M.V.Sc. Thesis, Fac. Vet. Med. Beni-Suef, Cairo Univ., Egypt.

Hayes, P. R. (1992): Food microbiology and hygiene. 2nd Ed., Elsevier Applied Science, London and New York.

Heyman, M. (2000): Effect of lactic acid bacteria on diarrhoeal disease. J. Am. Coll. Nutr., 19(2 suppl): 137S$146 \mathrm{~S}$.

IDF "International Dairy Fedration" (1996): Bacteriological quality of raw milk. 41 Square Vergote, B. 1030, Brussels, Belgium.

Jay, J. M. (1996): Modern Food Microbiology. $5^{\text {th }}$ Ed. Chapman \& Hall 1115 Fifth Avenue New York, NY 10003

Kamat, M.Y; Sulebele, G. and Nirupama, Sabanis (1991): A comparative evaluation of media for enumeration of Enterotoxigenic Staphylococci by selective enrichment technique. J. Food Sci. Technol., India, 28(6); 381 - 383.

Kivaria, F. M.; Noordhuizen, J. P. T. M. and Japaga, A. M. (2006): Evaluation of the hygienic quality and associated public health hazards of raw milk marketed by smallholder dairy producers in the Dar es Salaam region, Tanzania. Trop. Animal Hlth Prod., 38(3): 185-194.

Laine, E. S.; Scheftel, J. M.; Boxrud, D. J. ; Vought, K. J. ; Danila, R.N.; Elfering, K. M. and Smith, K. E. (2005): Outbreak of Escherichia coli O157:H7 Infections Associated with No intact Blade-Tenderized Frozen Steaks Sold by Door-to-Door Vendors. J. Food Protect., 68(6): 1198-1202.

Libouga, D. G.; Ngang, J. J. E. and Halilou, H. (2005): Quality of some Cameroonian fermented milk. Sci. des Aliments. 25(1): 53-66.

Ling, E. R. (1963): Text book of dairy chemistry 3rd Ed. 11: 1-30, Chapman and Hall, London.

Marshall, R.T. (1992): Standard methods for the examination of dairy products. 16th ed., American Public Health Association, Washington, DC.

Marth, E. H. and Steel, J. J. (2001): Applied dairy microbiology. $2^{\text {nd }}$ Ed. Dekker, Am, Inc., USA.

Mead, P. S.; Slutsker, L.; Dietz, V.; McCaig, L. F.; Bresee, J. S.; Shapiro, C.; Griffin, P. M. and Tauxe, R. V. (1999): Food-related illness and death in United States. Emerg. Infect. Dis., 5: 607-625.

Mossel, D. A. A. (1982): Microbiology of Food. $3^{\text {rd }}$ Ed. The University of Utrech. The Netherlands ISBN. 
Mossel, D. A. A.; Bijker, P. G. H. and Felderink, I. (1978): Arch. Lebensmittel HJg. 29, 121-127.

Motlagh, A. M.; Johnson, M.C. and Ray, B. (1991): Viability loss of Food borne pathogens by starter culture metabolites. J. Food Prot. Ames, Lowa: International Association of Milk, Food and Environmental Sanitarians; 54(11): 873-875.

Pazakova, J.; Turek, P. and Laciakova, A. (1997): The survival of staphylococcus aureus during the fermentation and storage of yoghurt. J. of Appl. Microbiol. 82(5): 659662

Robinson, R. K. (1990): Dairy microbiology, Vol. 2, Elsevier Applied Science, London and New York.

Rodriguez, A. C.; Pintor, D. M. C.; Gonzalez, P. A.; Alvarez, H. R. and Hadisson, D.T.A. (1990): Microorganisms of food hygiene interest in commercial yoghurt in the Canary Islands. Alimentaria 212:55-58. Dairy Sci. Abs. 57, 7892.

Roushdy, I. M.; Ehrman, M. A. and Vogel, R. F. (1998): Molecular identification and characterization of halotolerant lactic acid bacteria isolated from pickled Damietta cheese. Advances in Food Sci. 20: 40-45.

Schiemann, D. A. (1989): Yersinia enterocolitica and Yersinia pseudotuberculosi: In Food borne Bacterial pathogens ed. Doyle, M.P.pp. 601-672. New York, Ny: Marcel Dekker Inc.

Schiemann, D. A. and Wauters, G. (1992): Yersinia pp 433- 450. In; Vanderzant, C. and Splittstoesser, D.F. (ed) Compendium of methods for the microbial examination of foods. APHA. Washington, D.C., U.S.A.
Todorvic, M. and Salatic, Z. (1990): Inhibitory activity of the yoghurt culture on the growth of the food miocroflora. Brief Communication of the XXIII International Dairy Congress, Montreal, October 8-12, (1990) 1, 157 (289). Brussels, Belgium, International Dairy Federation. Dairy Sci. Abtrs., (1991) 53, 4656.

Ucar, G.; Guner, A.; Atasever, M. and Dogruer, Y. (2001): Some quality characteristics of sheep's milk yoghurt consumed in Konya region. Hayvanclk-Arastirma-Dergisi. 11(1): 50-52.

Varnam, A. H. and Sutherlands, J. P. (1994): Milk and Milk products. 1st Ed. Chapman and Hall Ltd., London.

Vyletelova, M. (2005): Quality of raw milk samples from North Moravia. Vyzkum-v-Chovu-Skotu. 47(2): 18-23.

Vyletlova, M. and Hanus, O. (2005): Occurrence of selected food borne pathogens in the course of UHT milk, Yoghurt and cheese production. Veterinarstvi. 55(9): 567572.

Yucel, N. and Ulusay, H. (2006): A Turkey survey of hygiene indicator bacteria and Yersinia enterocolitica in raw milk and cheese samples. Food control 17 (5): 383-388.

Zaria, L.T.; Osiyemi, T. I. O.; Suleman, M.A. and Shehu, L.M. (1998): The bacteria quality of the indigenously fermented milk product - 'nono' in Maiduguri municipality, Nigeria. Nigerian Journal of Animal Production. 25(1/2): 71-73.

Zedan, M. A.; Zedan, A. N.; Kebary, K. M. K. and Mahmoud, S. F. (2001): Effects of fortification of cows milk with acetylated whey protein concentrates on the quality of set yoghurt. Egyptian J. Dairy Sci., 29: 285-297.

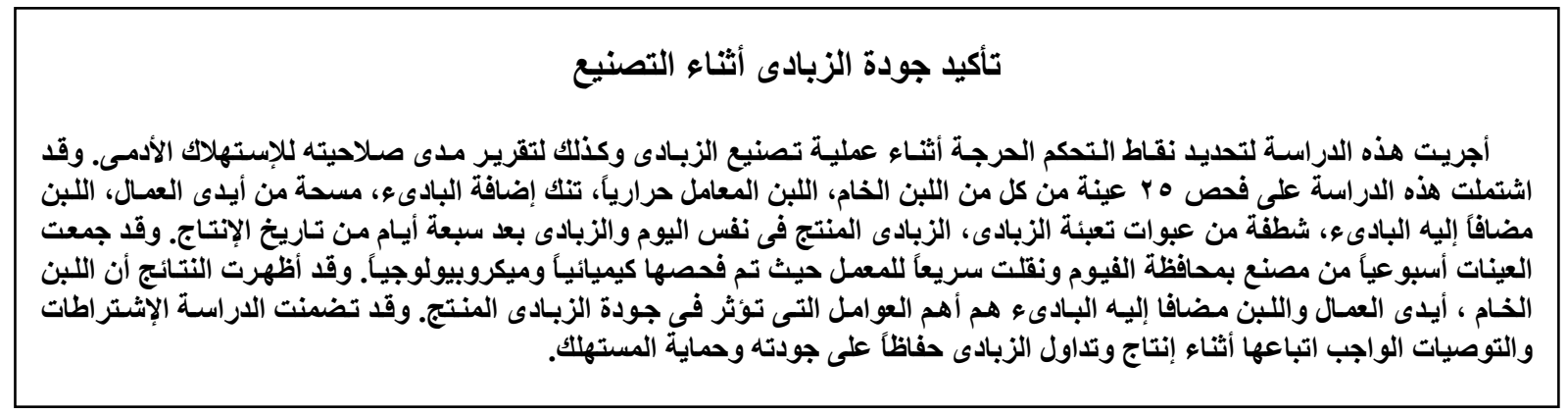

